\title{
Terapi Bermain Dengan Cbpt (Cognitive Behavior Play Therapy) Dalam Meningkatkan Konsentrasi Pada Anak ADHD
}

\author{
Ella Kholilah $^{1 *}$, Yulia Solichatun ${ }^{1}$ \\ 1. Fakultas Psikologi Universitas Islam Negeri Maulana Malik Ibrahim Malang \\ *E-mail: ellakholilah@gmail.com
}

\begin{abstract}
Abstrak
ADHD merupakan gangguan pada anak yang timbul pada masa perkembangan dini (sebelum berusia 7 tahun) dengan ciri utama ketidakmampuan memusatkan perhatian, impulsif, dan hiperaktif. Menurut DSM IV-TR (2005) bahwa anak dengan gangguan ADHD mempunyai ciri-ciri sering gagal dalam memberi perhatian terhadap suatu kegiatan dan kesulitan menjaga perhatian (konsentrasi) dalam menerima tugas dan kegiatan bermain. Oleh sebab itu, diperlukan adanya suatu penanganan khusus untuk meningkatkan konsentrasi, menurunkan gejala hiperaktivitas dan impulsivitas pada anak ADHD. Salah satu penangananya melalui terapi bermain dengan basis terapi bermain kognitif-perilaku (CBPT). Penelitian ini bertujuan untuk mengetahui terapi bermain dengan CBPT dapat meningkatkan pemusatan perhatian (konsentrasi) pada anak ADHD. Penelitian ini menggunakan pendekatan kuantitatif dengan metode kuasi eksperimen, metode pengumpulan data menggunakan observasi. Analisa data yang digunakan adalah analisa grafik deskriptif. Hasil penelitian menunjukkan bahwa terapi bermain dapat meningkatkan konsentrasi pada anak ADHD.
\end{abstract}

\section{Kata kunci: ADHD, CBPT, Konsentrasi, Terapi Bermain}

\section{Mukadimah}

Setiap orangtua selalu menginginkan anaknya tumbuh dan berkembang secara sempurna. Anak yang berprestasi, kooperatif, dan secara fisik tidak ada kekurangan, itulah dambaan setiap orangtua, namun "Apa yang terjadi apabila sebaliknya?", Orangtua seringkali bingung dan gelisah karena perilaku anaknya tidak seperti anak biasanya yaitu anak yang mengalami berkebutuhan khusus atau yang disingkat dengan ABK. Anak Berkebutuhan Khusus (ABK) diartikan sebagai anak dengan karakteristik khusus yang berbeda dengan anak pada umumnya yang selalu menunjukkan ketidakmampuan mental, emosi, atau fisik namun mereka tetap harus mendapatkan pendidikan.

Ungkapan senada juga ditegaskan dalam Undang-Undang Nomor 20 Tahun 2003 tentang Sistem Pendidikan Nasional terutama pasal 5 ayat (2) bahwa warga negara yang memiliki kelainan fisik, emosional, mental, intelektual, dan sosial berhak memperoleh pendidikan khusus. Pada pasal 32 ayat (1) bahwa pendidikan khusus merupakan pendidikan bagi peserta didik yang memiliki tingkat kesulitan dalam mengikuti proses pembelajaran karena kelainan fisik, emosional, mental, sosial, dan atau memiliki potensi kecerdasan dan bakat istimewa. Salah satu dari ABK adalah anak dengan gangguan ADHD. ADHD Adalah gangguan pada anak yang timbul pada masa perkembangan dini (sebelum berusia 7 tahun) dengan ciri utama ketidakmampuan memusatkan perhatian, impulsif, dan hiperaktif. ADHD merupakan salah satu contoh dari ABK yang berhak memperoleh pendidikan khusus. Ciri-ciri anak ADHD harus diminimalisir agar mudah untuk menangkap informasi dan memperoleh pendidikan. Salah satunya yaitu anakanak ADHD di SLB Lab Autis UNM. Mereka perlu diberikan penanganan agar mampu memusatkan perhatian, perilaku impulsif dan hiperaktif dapat diminimalisir. 
Menurut DSM IV T-R, terdapat 3 karakteristik utama gangguan ADHD, yakni Inattention (kesulitan memusatkan perhatian) dimanifestasikan dalam bidang akademik, mengerjakan tugas atau berbagai situasi sosial, dengan gejala seperti gagal memusatkan perhatian pada hal-hal yang kecil, dan sering melakukan kekeliruan pada pekerjaan sekolah. Impulsivitas (kesulitan menahan keinginan) seperti tidak sabar, kesulitan saat harus menunggu, kesulitan pada saat harus menunda respon, dan seringkali menyela atau menginterupsi serta hiperaktivitas (kesulitan mengendalikan gerakan) seperti kegelisah, gerakan-gerakan saat duduk, tidak duduk kembali saat mengerjakan sesuatu, berlari, naik-naik dalam situasi yang tidak tepat, dan suka berpindah-pindah tempat.

Prevalensi kejadian ADHD di Indonesia belum ada data nasional yang pasti karena belum banyak penelitian yang dilakukan. Menurut Judarwanto (2009) kejadian gangguan ADHD ini adalah sekitar 3 - 10\%, di Amerika Serikat, sekitar 3-7\% sedangkan di negara Jerman, Kanada dan Selandia Baru sekitar 5-10\%. Diagnosis and Statistic Manual (DSM IV) menyebutkan prevalensi kejadian ADHD pada anak usia sekolah berkisar antara 3 hingga 5 persen. Marlina (2007:20) menyatakan bahwa di Indonesia sampai saat ini belum ada dilakukan survei tentang ADHD, kalaupun ada hanya pada daerah-daerah tertentu dan belum terintegrasi. Suhartini (2002) misalnya dari hasil surveinya pada anak TK se Kotamadya Yogyakarta dari 3233 anak TK ditemukan $1,76 \%$ anak dikategorikan mengalami ADHD (dalam Anjani, 2013: 126).

Fenomena yang telah dijelaskan di atas kita mengetahui bahwa di Indonesia banyaknya anak ADHD yang belum masuk dalam data nasional, namun kasus ADHD untuk anak pra-sekolah dan sekolah masih banyak terjadi. Hal ini memotivasi peneliti untuk melakukan penelitian dalam mengakaji kasus anak ADHD dan penanganannya. Oleh sebab itu diperlukan adanya suatu penanganan khusus untuk meningkatkan konsentrasi, menurunkan gejala hiperaktivitas dan impulsivitas pada anak ADHD berupa sebuah terapi.

Menurut Hall, Kaduson dan Schaefer (2002) salah satu terapi lain untuk ADHD adalah terapi bermain. Menurut anak-anak bermain adalah dunia mereka dan bermain merupakan kegiatan yang dapat mengungkapkan suatu bahasa yang paling universal bagi anak sehingga melalui bermain anak dapat mengekspresikan apapun yang diinginkannya (dalam Hatiningsih, 2013: 327).

Terapi bermain ini digunakan sebagai cara untuk membantu anak ADHD dalam mengkomunikasikan ide dan perasaannya mereka ketika penalaran abstrak dan kemampuan verbal yang dibutuhkan untuk mengartikulasi perasaan, pikiran, dan perilaku mereka belum berkembang secara optimal (Hall, Kaduson, \& Schaefer, 2002: 515). Terapi bermain, CBPT (Cognitive Behavior Play Therapy), dan CCPT (Client Centered Play Therapy) digunakan untuk anak-anak ADHD. Studi menemukan bahwa terapi bermain dan terapi bermain kognitif-perilaku (CBPT) efektif untuk meningkatkan perhatian anak-anak ADHD, impulsif, dan pengendalian diri (Choi, 2012).

Terapi bermain adalah permainan yang merupakan pintu masuk ke dalam dunia anak-anak. Anak-anak dapat mengekspresikan kreativitasnya melalui bermain. Dan Haim G. Ginott menciptakan istilah, "Mainan adalah kata-kata anak dan bermain adalah bahasa anak" (Homeyer dan Morrison 2008: 212).

Beranjak dari permasalahan di atas, peneliti tertarik ingin mengetahui apakah ada peningkatan fokus (konsentrasi) anak ADHD dari penerapan terapi bermain melalui permainan-permainan menarik. Setelah melakukan wawancara bersama salah satu guru di SLB Lab Autis UNM mengatakan bahwa terapi bermain merupakan terapi yang menarik namun khusus untuk anak ADHD sendiri merupakan inovasi baru untuk dapat dipelajari.

ADHD adalah istilah popular, kependekan dari attention deficit hyperactivity disorder; (Attention= perhatian, Deficit= berkurang, Hyperactivity =hiperaktif, dan Disorder= gangguan). Dalam bahasa Indonesia ADHD adalah gangguan pemusatan perhatian disertai hiperaktif. Secara umum ADHD adalah memperlihatkan kondisi anak-anak dengan ciri-ciri dan gejala kurangnya pemusatan perhatian, perilaku hiperaktif, dan perilaku impulsif yang dapat menyebabkan sebagian besar ketidakseimbangan aktivitas hidup mereka (Baihaqi \& Sugiarmin, 2006:2). 
Senada dengan yang dikatakan oleh Patternotte dan Buitelaar, (2010:2) ADHD adalah singkatan dari Attention Deficit Hyperactivity Disorder, atau dalam bahasa Indonesia disebut dengan Gangguan Pemusatan Perhatian dan Hiperaktivitas (GPPH). ADHD adalah suatu gangguan neuro-biologis di dalam otak yang dapat secara parah mengancam tumbuh kembang seorang anak. Anak ADHD seringkali tidak dapat dikendalikan, tidak tenang, dan tidak dapat berkonsentrasi. Karena itu, dia kemudian mengalami kesulitan, baik di rumah maupun di sekolah. Perilakunya yang kacau itu justru mengundang kejengkelan bagi orang-orang disekitarnya. Akibatnya adalah ia kesulitan mendapatkan teman. Kondisi ini dapat membawanya pada masalah-masalah emosional, agresif atau sebaliknya perilaku menarik diri dan depresi (Paternotte \& Buitelaar. 2010).

Kriteria ADHD berdasarkan Diagnostic Statistic Manual DSM IV (dalam Baihaqi dan Sugiarmin, 2006: 8) Karakteristik ADHD secara internasional menjelaskan dalam buku rujukan diagnosis psikiatri DSM (Diagnostic and Statistical Manual of Mental Health Disorder), yaitu apabila seseorang anak menampilkan beberapa gejala dari gangguan perhatian dan konsentrasi, impulsivitas dan hiperaktivitas. Gejala-gejala ini haruslah sudah tampak sejak amat dini sekali (sebelum usia 7 tahun).

Salah satu ciri-ciri ADHD yaitu kurang pemusatan perhatian yang berkaitan dengan atensi dan kesadaran. Atensi adalah cara-cara kita secara aktif memproses sejumlah informasi yang terbatas dari sejumlah besar informasi yang disediakan oleh indra, memori yang tersimpan, dan oleh prosesproses kognitif kita yang lain. Atensi menjadi cukup baik proses-proses sadar maupun bawah sadar. Proses-proses sadar realtif mudah untuk dipelajari di banyak kasusnya. (Sternberg, 2006:58). Kesadaran yaitu mencakup perasaan tentang apa yang disadari maupun isinya, yang darinya bisa kita gunakan untuk memfokuskan atensi. Oleh karena itulah, atensi dan kesadaran membentuk dua sistem yang tumpang tindih. Kesimpulannya, atensi dan kesadaran diperlukan untuk memproses sejumlah informasi yang didapat dengan fokus (sadar) atau konsentrasi.
Anak-anak dengan tipe ADHD menunjukkan ketidakmampuan memberikan atensi memiliki beberapa simtom. Pertama, perhatian mereka mudah teralihkan oleh pemandangan bunyi yang tidak relevan. Kedua, mereka sering gagal memberikan atensi kepada hal-hal detail. Ketiga, mereka cenderung bertindak ceroboh dalam tugastugas mereka. Keempat, mereka sering gagal untuk membacakan instruksi sepenuhnya atau dengan hati-hati. Kelima, mereka mudah melupakan atau mengabaikan hal-hal yang mereka butuhkan untuk menyelesaikan tugas seperti pensil dan buku. Akhirnya, keenam, mereka cenderung melompat dari satu tugas ke tugas lain padahal tugas itu belum selesai (Sternberg, 2008:97).

Berdasarkan penjelasan di atas dapat disimpulkan bahwa perlunya penanganan berupa sebuat terapi. Salah satunya yaitu dengan terapi bermain dengan terapi bermain kognitif-perilaku (CBPT). Terapi bermain kognitif-perilaku didasarkan pada teori kognitif gangguan emosional dan prinsip terapi kognitif dan menyesuaikan halhal ini dalam cara yang sesuai. Knell (1993a, 1993b, 1994, 1997, 1998) berpendapat bahwa Cognitive Therapy (CT) dapat dimodifikasi untuk penggunaan dengan anak-anak jika disajikan dengan cara yang sangat mudah diakses untuk anak. (Schaefer, 2011: 314). Prinsip Terapi Bermain Kognitif-Perilaku (CBPT) didasarkan pada model kognitif gangguan emosional dan bersifat singkat, terbatas waktu, terstruktur, direktif, berorientasi, dan psikoedukasional. Hubungan terapeutik yang aman adalah kondisi yang diperlukan untuk CBPT yang efektif (Schaefer, 2011: 316).

Metode dalam Terapi Bermian KognitifPerilaku (CBPT) yaitu sebagian besar intervensi behavioral kognitif dengan anak-anak meliputi beberapa bentuk peragaan. Ini benar khususnya untuk CBPT, dimana peragaan adalah komponen penting. Peragaan adalah cara yang efisien dan efektif untuk belajar, dan juga memperoleh, memperkuat, atau memperlemah perilaku (Bandura, 1977). Peragaan yang didesain untuk meningkatkan skill seringkali melibatkan model adaptasi. Model adaptasi menampilkan skill-skill yang kurang ideal dan kemudian perlahan menjadi lebih mahir. Kemanjuran peragaan meningkat dengan penggunaan model-model adaptasi (Bandura \& Menlove, 1968; Meichenbaum, 1971 dalam 
Schaefer, 2011: 317). Lebih jarang digunakan dalam CBPT, namun masih merupakan metode intervensi penting, adalah role-play, dimana anak mempraktekkan skill-skill dengan ahli terapi dan menerima umpan balik terus-menerus. Role-play biasanya lebih efektif untuk anak-anak usia sekolah, meskipun bisa saja menghadirkan role-play melalui teknik peragaan. Dalam cara ini, peraga benar-benar bermain role-play, dan si anak mengamati dan belajar dari melihat peraga mempraktekkan skill tertentu (Schaefer, 2011: 317-318).

\section{1) Intervensi behavioral (perilaku) dalam CBPT}

Sebuah jenis teknik yang didasarkan pada tiga model terapi perilaku (pengkondisian klasik, pengkondisian operan, pembelajaran sosial) dapat digabungkan ke dalam terapi permainan. Teknikteknik dari pengkondisian klasik (misal, desensitisasi sistematis) dan operan (misal, manajemen kontigensi, pembentukan, penguatan diferensial perilaku lain [DRO]) biasanya digunakan untuk membantu anak memasukkan perilaku yang lebih adaptif. Teknik-teknik dari teori pembelajaran sosial (misal, peragaan) digunakan secara ekstensif dalam CBPT, memanfaatkan pembelajaran observasional sebagai alat untuk mempelajari perilaku baru (Schaefer, 2011 : 319).

\section{2) Intervensi kognitif dalam CBPT}

Metode-metode behavioral dalam CBPT biasanya melibatkan perubahan aktifitas, sedangkan metode-metode kognitif berurusan dengan perubahan pemikiran. Karena pikiran-pikiran maladaptif diduga mengakibatkan perilaku maladaptif, perubahan pikiran harus menghasilkan perubahan perilaku. Ahli terapi membantu anak menemukan, memodifikasi, dan/atau membentuk kognisi. Melalui cara ini, anak-anak belajar untuk mengidentifikasi pikiran-pikiran maladaptif dan menggantinya dengan pikiran-pikiran yang adaptif (Schaefer, $2011: 320$ ).

Metode perilaku dalam CBPT biasanya melibatkan perubahan dalam aktivitas, sedangkan metode kognitif menghadapi perubahan dalam berpikir karena pikiran maladaptif yang diduga menyebabkan perilaku maladaptif. Perubahan dalam berpikir harus menghasilkan perubahan perilaku. (Knell dalam Schaefer : 2015: 315).
Ada beberapa penangan untuk meningkatkan konsentrasi anak ADHD seperti terapi bermain dan CBPT (Cognitive-Behavioural Play Therapy) terapi ini termasuk dalam terapi bermain yang melibatkan aspek kognitif dan perilaku. Salah satu tujuan dalam terapi ini yaitu "Quieting down of the hyperactive organization (Rachman, 1986)" dimana dalam tujuan CBPT yaitu menenangkan/meredakan organisasi hiperaktif anak. (Braverman and O'Cornoor 2009: 206).

Berdasarkan dari penjelasan di atas diambil hipotesis dalam penelitian ini yaitu terapi bermain melalui terapi bermain kognitif perilaku (CBPT) dapat meningkatkan konsentrasi pada anak ADHD.

\section{Metode}

Penelitian ini termasuk dalam penelitian kuasi eksperimen. Kuasi eksperimen yang dilakukan dalam penelitian ini menyangkut subjek individu, jadi penelitian ini termasuk dalam kuasi eksperimen tunggal. Menurut Latipun (2002:99) desain kuasi ekperimen ini termasuk dalam kategori penelitian single-case experimental design yaitu merupakan sebuah desain penelitian untuk mengevaluasi efek suatu perlakukan (intervensi) dengan kasus tunggal (Kazdin, 1992). Kasus tunggal dapat berupa beberapa subjek dalam satu kelompok atau subjek yang diteliti adalah tunggal $(\mathrm{N}=1)$. Sedangkan dalam rancangan penelitian dalam penelitian ini menggunakan A-B yang melibatkan fase baseline (A) dan fase perlakuan (B).

Variabel dalam penelitian ini ada dua yaitu variabel bebas terapi bermain yang diberikan oleh terapis dengan pendekatan terapi bermian kognitif-perilaku (CBPT) dan variabel terikat yaitu peningkatan konsentrasi pada anak dengan gangguan ADHD, yang ditandai dengan perilaku (a) dapat memperhatikan baik-baik terhadap sesuatu yang detail atau tidak membuat kesalahan yang sembrono dalam kegiatan sekolah dan kegiatan lainnya, (b) tidak mengalami kesulitan dalam memusatkan tugas-tugas kegiatan bermain, (c) mengikuti baikbaik instruksi dan bisa menyelesaikan suatu pekerjaan, (d) mendengarkan jika diajak bicara secara langsung, (e) tidak terganggu oleh rangsangan dari luar, (f) bisa menyelesaikan kegitan dengan baik. 
Definisi operasional yaitu ADHD menjelaskan kondisi anak-anak yang memperlihatkan simtomsimtom (ciri dan gejala) kurang konsentrasi, hiperaktif dan impulsif yang dapat dideteksi sejak dini dan dapat menyebabkan kekacauan sebagian besar aktivitas kegiatan mereka. Adapun terapi bermain adalah proses terapeutik dilakukan dalam kegiatan bermain agar mudah melihat suatu permasalahan melalui ekspresi alami seorang anak yang tidak bisa diungkapkannya dalam bahasa verbal, dirancang untuk mengetahui permasalahan anak dan bagaimana mengatasinya. Adapun dalam penelitian ini menggunakan Terapi Bermain Kognitif-Perilaku (Cognitive-Behavioral Play Therapy) dengan menggunakan beberapa permainan menarik.

Populasi yang digunakan adalah jumlah anak ADHD yang ada di SLB Lab Autis UNM. Teknik pengumpulan sampel dalam penelitian ini menggunakan teknik purposive sampling. Pengambilan teknik purposive sampling ini dilakukan dengan melakukan pemilihan sampel sesuai dengan yang dikehendaki (Latipun, 2011: 30). Subjek dalam penelitian ini adalah anak yang mengalami ganggan ADHD sebanyak 2 orang.

Metode pengumpulan data dalam penelitian ini dengan menggunakan observasi tingkah laku kurangnya pemusatan perhatian/sulit berkonsentrasi. Pengumpulan data dilakukan saat observasi dan saat dilakukannya terapi dengan cara mengamati perilaku pemusatan perhatian/berkonsentrasi.

Instrument yang digunakan dalam penelitian ini adalah lembar evaluasi dan observasi rating-scale pada perilaku pemusatan perhatian/ berkosentrasi pada anak ADHD yang terdiri dari 6 indikator dan 8 item, modul Terapi Bermain dan ruangan yang digunakan untuk proses terapi.

Reliabilitas yang digunakan dalam penelitian dengan menentukan kriteria stabilitas terlebih dahulu dengan kriteria stabilitas $15 \%$, kemudian ditentukan presentase stabilitas. Apabila presentase stabilitas sebesar $85 \%$ - 90\% dikatakan stabil, sedangkan di bawah itu dikatakan tidak stabil (variabel) (Suananto, Takeuchi, \&Nakata, 2005:94).
Analisis data dalam penelitian ini adalah deskripsi gambaran yang diperoleh dari analisa grafik dan proses observasi rating scale berdasarkan pengukuran perilaku. Proses analisa data pada penelitian subjek tunggal banyak mempresentasikan data ke dalam grafik garis. Grafik memegang peran penting dalam proses analisis pada penelitian ini.

\section{Hasil}

Data ini dihasilkan dari hasil pelaksanaan penelitian sebanyak 10 sesi yang dibagi menjadi 2 sesi yaitu 5 sesi pada baseline ( 1 hari 1 sesi dengan durasi waktu 45 menit untuk 1 subjek) dan 5 sesi pada intervensi (1 hari 1 sesi dengan durasi waktu 20-30 menit untuk 1 subjek). terapi bermain hari pertama yaitu Simons Says, hari kedua yaitu The Feeling Word Game, hari ketiga yaitu Jenga, hari keempat yaitu Simons Says dan hari kelima yaitu Jenga.

Tabel 3. Deskripsi subjek penelitian

\begin{tabular}{ccccc}
\hline Nama & $\begin{array}{c}\text { Jenis } \\
\text { kelamin }\end{array}$ & Umur & Pendidikan & Kelas \\
\hline D & L & 11 & $\begin{array}{c}\text { SLB Lab Autis } \\
\text { UNM }\end{array}$ & IV \\
A & L & 10 & $\begin{array}{c}\text { SLB Lab Autis } \\
\text { UNM }\end{array}$ & I \\
\hline
\end{tabular}

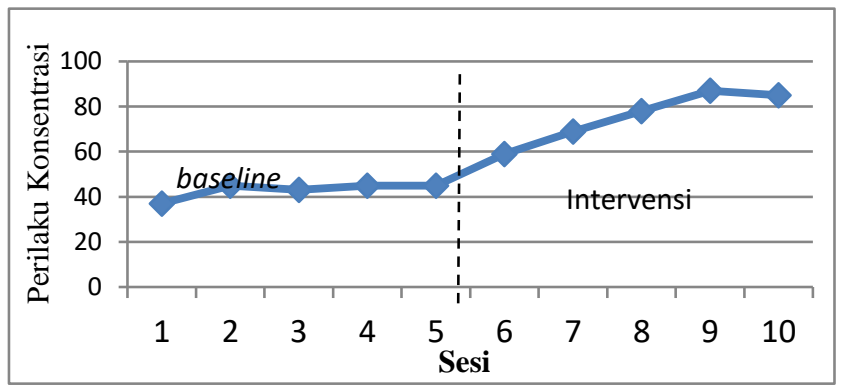

Gambar 1. Analisis visual baseline dan intervensi pada subjek D

Perilaku subjek pertama (Subjek D) setelah dimasukkan dalam grafik visual baseline dan intervensi bahwasannya perilaku konsentrasi mengalami peningkatan, sesi 1 observasi subjek memiliki frekuensi perilaku berkonsentrasi sebanyak 37, pada sesi 2 perilaku konsentrasi subjek mengalami kenaikan sebanyak 45, pada sesi 3 
frekuensi perilaku konsentrasi subjek mengalami penurunan menjadi 43, pada sesi 4 dan 5 mengalami kenaikan menjadi 45. Perilaku konsentrasi subjek stabil berada direntang 40-50 pada sesi 2 sampai sesi 5 . Sesi keenam atau sesi pertama pada intervensi mengalami peningkatan yaitu 59 dan begitu pula pada sesi berikutnya mengalami peningkatan frekuensi perilaku konsentrasi subjek yaitu 69, 78, dan 87. Namun, pada sesi terakhir subjek mengalami penurunan frekuensi perilaku konsentrasi menjadi 85 .

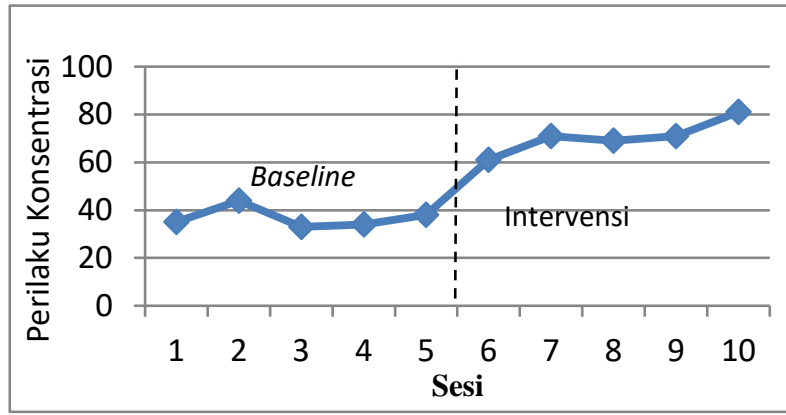

Gambar 2. Analisis visual baseline dan intervensi pada subjek $A$

Perilaku subjek kedua (subjek A) setelah dimasukkan dalam grafik visual baseline dan intervensi bahwasannya perilaku konsentrasi mengalami peningkatan, sesi 1 observasi subjek memiliki frekuensi perilaku berkonsentrasi sebanyak 35, sesi ke 2 perilaku konsentrasi sebanyak 44 kali yaitu mengalami peningkatan, sesi ke-3 perilaku konsentrasi sebanyak 33 kali mengalami penurunan, dan mengalami peningkatan pada sesi-sesi selanjutnya yaitu sebanyak 34 dan 38 kali. Sesi keenam atau sesi pertama pada intervensi menunjukkan perilaku konsentrasi sebanyak 61 kali, pada sesi ke 7 juga mengalami peningkatan frekuensi perilaku konsentrasi sebanyak 71 kali, namun pada sesi kedelapan mengalami penuruan frekuensi perilaku sebanyak 69, begitu selanjutnya mengalami peningkatan sesi kesembilan dan kesepuluh sebanyak 71 dan 81 .

Intervensi yang diberikan berupa terapi bermain berbasis CBPT tersebut mempunyai hasil positif. Hal ini terlihat pada grafik perilaku subjek pertama subjek D dan subjek A pada saat fase intervensi meningkat daripada fase baseline sehingga dapat dipastikan bahwa kedua subjek mengalami peningkatan dalam perilaku pemusatan perhatian (konsentrasi).

Adapun permainan tersebut digunakan dengan terapi bermain kognitif perilaku (CBPT) sebagai berikut:

\section{Simons Says}

Permainan itu mengharuskan anak untuk mengikuti aturan yang diberikan oleh pemimpin sehingga anak belajar untuk mengontrol impuls dengan menunggu instruksi yang diberikan, mematuhinya, dan akan ada saatnya mereka yang menjadi pemimpin dalam permainan. Tujuan dari permainan ini adalah agar anak dapat mengontrol perilaku impuls dan fokus untuk jangka waktu tertentu. Manfaat permainan ini dapat meningkatkan kontrol diri pada anak-anak ADHD, meminimalisir perilaku impulsif yang sering terjadi, menahan gangguan serta fokus pada jangka waktu tertentu.

Permainan yang terdiri dari dua orang/lebih. Salah satu pemain berperan sebagai Simon yang akan memberikan instruksi. Pemain lain akan mengerjakan instruksi yang diberikan Simon. Contoh : "Simon says... Maju ke depan dua langkah dan ke kanan satu langkah"; "Simon says... Jalan sambil jongkok!"'. Namun, jika leader memberikan instruksi tanpa berkata "Simon says..." maka pemain lainnya tidak boleh mengikuti instruksi. Pemain dapat bertukar peran sesuai dengan perjanjian yang dibuat.

Permainan ini menggunakan metode CBPT berupa Peragaan dengan dasar modeling dan penguatan positif (reinforcement).

Adapun peragaan dengan dasar modeling dalam permainan Simons Says, yaitu subjek diberikan contoh oleh terapis bagaimana cara memainkan permainan simons says. Hal ini sama dengan modeling dalam teori Albert Bandura, subjek melakukan (a)perhatian (attention), subjek melihat perilaku terapis dalam memperagakan permainan 
simons says, yaitu kapan saatnya subjek merespon apa yang dikatakan terapis dan kapan saatnya subjek tidak mengikuti apa yang dikatakan terapis. (b) pengendapan (retention), dilakukan setelah subjek mengamati perilaku yang akan ditiru dan menyimpan setiap informasi yang didapat dalam ingatan. (c) reproduksi motorik (reproduction), subjek memulai permainan dengan meniru apa yang dikatakan oleh terapis, dan (d) penguatan (motivasi) yang akan dibahas di bawah ini (Alwisol, 2009: 293-294).

penguatan positif yang diberikan dalam permainan ini yaitu penguatan positif berupa pujian, penguatan ini diberikan ketika subjek telah berhasil melakukan satu kegiatan dan terapis memberikan pujian pada subjek seperti "anak pintar, tos dulu sama ibu", "baguss peluk ibu dulu sini”.

Berdasarkan penjelasan di atas yaitu terapi bermain dengan metode CBPT seperti peragaan (modeling) dan penguatan positif (reinforcement) efektif untuk membentuk perilaku konsentrasi subjek.

\section{The Feeling Word Game}

Permainan ini di adaptasi dari permainan "The Feeling Word Game" yang di jelaskan oleh Kaduson \& Schaefer (1997). permainan The Feeling Word Game adalah permainan kata perasaan dirancang dengan gambar-gambar dengan emosi-emosi yang berbeda-beda. Schaefer menyatakan permainan ini dirancang untuk meningkatkan kontrol diri anak-anak, memahami emosi dan prilaku implusif. Tujuan dari permainan ini adalah agar anak dapat menahan gangguan serta fokus untuk jangka waktu tertentu. Memahami emosi dan meminimalisir perilaku impulsif. Manfaat permainan ini dapat meningkatkan kontrol diri pada anak-anak ADHD, meminimalisir perilaku impulsif yang sering terjadi, menahan gangguan serta fokus pada jangka waktu tertentu. Alat dan bahan dalam permainan ini yaitu 8 potongan kertas berukuran 4 X $6 \mathrm{~cm}$, spidol, meja, kursi, stopwatch.

Cara bermain yaitu terapis duduk di meja yang sama dengan subjek atau dapat duduk dilantai, media yang digunakan berupa 8 potongan kertas berukuran 4 X $6 \mathrm{~cm}$, spidol yang sebelumnya ditandai dengan gambar-gambar bentuk perasaan seperti senang (tertawa), sedih, cemas, takut, menangis. Permainan dibuka dengan perkenalan emosi-emosi tersebut pada subjek. Kemudian terapis mencontohkan dengan mengambil salah satu kartu tertawa. Lalu terapis menceritakan pengalamannya ketika tertawa. Begitupula dengan kartu menangis, apabila terapis mengambil kartu menangis maka terapis akan menceritakan pengalamannya ketika menangis.

Permainan ini menggunakan metode CBPT berupa Role-Paly dengan dasar modeling dan penguatan positif (reinforcement). role-play yaitu anak mempraktikkan skill-skill dengan ahli terapi dan menerima umpan balik terus-menerus, hal ini sama dengan peragaan namun role-play memerlukan umpan balik (feedback) dari subjek. Subjek mengamati dan belajar dari melihat peraga mempraktikkan skill tertentu (Schaefer, 2011: 317318). Dalam permainan ini subjek melakukan permainan dengan adanya umpan balik dari terapis seperti:

Terapis : "baik sekarang terapis mengambil kartu " senang", ibu pernah senang karena mendapatkan hadiah nah kamu pernah senang?" (menanyakan subjek)

Subjek : "pernah bu"

Terapis : "senang karena apa?"

Subjek :"karena jam istirahat bu"

Selanjutnya, adalah penguatan positif (reinforcement) dalam permainan The Feeling Word Game penguatan yang diberikan dalam 
permainan ini yaitu penguatan positif berupa pujian, penguatan ini diberikan ketika subjek telah berhasil melakukan satu kegiatan dan terapi memberikan pujian pada subjek seperti "wah bagus... ternyata kamu marah yaa kalau ada yang bohongin kamu, ayo terus apalagi yang bisa membuat kamu marah?", "wahhh hebat ternyata kamu senang kalau kamu jalan-jalan sama ibu dan ayah.. ayo..ayo apalagi yang bisa membuat kamu senang?."

Berdasarkan penjelasan di atas yaitu terapi bermain dengan metode CBPT seperti role-paly (modeling) dan reinforcement dalam permainan ini efektif untuk membentuk perilaku konsentrasi subjek.

\section{Jenga}

Permainan ini dilakukan untuk membantu mengendalikan aktivitas yang berlebihan (hiperaktivitas), melatih kemampuan mempertahankan perhatian pada objek tertentu, mengembangkan keterampilan menunggu giliran, dan mengendalikan tingkat agresivitas.

Cara memainkan permainan Jenga yaitu anak hanya harus menyusun balok ke atas dengan cara para pemain secara bergantian memindahkan satu balok yang berada paling bawah untuk diletakkan di atas balok yang paling atas. Jangan sampai balok yang anak susun dan pindahkan menjadi roboh, karena hal itu akan menyebabkan anak kalah dalam permainan. Anak harus memindahkan balok-balok tersebut agar tersusun dan tidak mudah roboh.

Permainan ini menggunakan metode CBPT berupa token ekonomi dan strategi perubahan kognitif/ melawan kepercayaan irrasional.

Token ekonomi digunakan untuk membentuk tingkah laku agar mendekati dengan target tujuan. Tingkah laku yang layak bisa diperkuat dengan perkuatan-perkuatan yang bisa diraba atau dilihat yang bisa ditukar dengan objek-objek atau hak istimewa yang diingini (Corey, 2005: 222) dalam permainan ini dilakukan dengan mengunakan stiker, subjek diberikan 1 stiker selama 30 detik ketika balok tersebut tidak roboh. Stiker yang banyak akan ditukarkan dengan hadiah, seperti 5 stiker mendapatkan tiga permen, 10 stiker mendapatkan coklat, dan 15 stiker mendapatkan susu milo, 2 coklat, dan nyam-nyam.

Selanjutnya, Subjek A diberikan strategi perubahan kognitif/ melawan kepercayaan irrasional, karena subjek A tidak ingin menunggu giliran bermain, ingin berhenti bermain dan sulit diajak bekerjasama dengan tim sehingga terapis melakukan pernyataan keyakininan diri positif kepada subjek A.. "ayoo kamu pasti bisaa... kamu bisaa melakukannya, ayoo ikuti ibu.. kamu bisa melakukannya!", kemudian subjek A bilang "aku bisa.. aku bisa."

Berdasarkan penjelasan di atas token ekonomi dan strategi perubahan kognitif / melawan kepercayaan irrasional dalam permainan Jenga efektif untuk membentuk perilaku konsentrasi subjek.

Berdasarkan analisis grafik yang telah dipaparkan, dapat disimpulkan bahwa hipotesis yang diajukan dapat diterima, yaitu terapi bermain melalui terapi bermain kognitif perilaku (CBPT) dapat meningkatkan konsentrasi pada anak ADHD. Hasil penelitian menunjukkan perubahan tingkat konsentrasi lebih tinggi pada fase intervensi dibandingkan pada fase baseline. walaupun perilaku konsentrasi subjek belum sepenuhnya dapat konsisten (stabil).

\section{Diskusi.}

Hasil penelitian menunjukkan adanya perubahan tingkat konsentrasi subjek setelah diberikannya terapi bermain dengan metode terapi bermain kognitif perilaku (CBPT). Terapi bermain kognitifperilaku didasarkan pada teori kognitif gangguan emosional dan prinsip terapi kognitif dan menyesuaikan hal-hal ini dalam cara yang sesuai (Schaefer, 2011: 314).

Pada intervensi terapi bermain ini dilakukan dengan metode CBPT adalah peragaan dengan konsep dasar 
modeling. Di mana sebagian besar intervensi behavioral kognitif dengan anak-anak meliputi beberapa bentuk peragaan. Ini benar khususnya untuk CBPT, di mana peragaan adalah komponen penting. Peragaan adalah cara yang efisien dan efektif untuk belajar, dan juga memperoleh, memperkuat, atau memperlemah perilaku (Bandura, 1977 dalam Schaefer, 2011:317). Peragaan yang melibatkan penambahan atau pengurangan tingkah laku yang teramati, menggeneralisir berbagai pengamatan sekaligus, dan juga melibatkan proses kognitif (Alwisol, 2009: 292).

Selain dengan modeling hal yang penting ada dalam terapi bermain metode CBPT ini yaitu reinforcement (penguatan). Menurut Bandura, kebanyakan belajar tanpa reinforcement (penguatan) yang nyata (Alwisol, 2009: 292). Hal ini benar adanya dalam permainan Simons Says dan The Feeling Word Game subjek diberikan reinforcement berupa pujian. Penguatan berupa pujian diberikan agar subjek termotivasi untuk menyelesaikan permainan.

Pada intervensi terapi bermain ini dilakukan dengan metode CBPT menggunakan token ekonomi, metode token ekonomi diberikan untuk membentuk tingkah laku apabila pemerkuat-pemerkuat yang tidak bisa diraba (seperti pujian) tidak memberikan pengaruh (Corey, 2013: 222). Perlunya tingkah laku subjek yang diperkuat dengan perkuatan yang bisa diraba (stiker) agar nantinya bisa ditukar dengan hadiah yang diingini. token ekonomi sangat mirip dengan kehidupan nyata, misalnya, para pekerja dibayar untuk hasil pekerjaan mereka (Corey, 2013 :223).

Selain dengan token ekonomi hal yang penting ada dalam terapi bermain metode CBPT ini yaitu strategi perubahan kognitif / melawan kepercayaan irrasional. Hal ini sesuai dengan yang dikatakan oleh Schroeder \& Gordon (1991) bahwa anak-anak seringkali memerlukan bantuan dalam mengembangkan pernyataan keyakinan diri positif (Velting dkk., 2004). Anak-anak perlu belajar cara bagaimana membuat pernyataan keyakinan diri positif secara jelas dan sederhana secara linguistik dan konsep (misal, "Aku kuat"; "Aku bisa melakukan ini") (Schaefrer, 2011 : 321). Dengan melakukan pernyataan linguistik yang sederhana kepada subjek untuk mengubah keyakinan diri negatif menjadi positif dapat membantu membentuk perilaku baru terutama dalam perubahan kognitif subjek.

Berdasarkan penjelasan diatas di atas dapat diketahui bahwa efektivitas terapi bermain Jenga Simons Says dan The Feeling Word Game berpengaruh karena adanya modeling, reinforcement, token ekonomi dan strategi perubahan kognitif / melawan kepercayaan irrasional dalam meningkatkan konsentrasi subjek. Maka hasil penelitian ini sejalan dengan yang disampaikan oleh Choi (2013) bahwa terapi bermain dengan CBPT (Cognitive-Behavioral Play Therapy) efektif untuk meningkatkan perhatian anak-anak ADHD, impulsif, dan pengendalian diri. Hal ini juga sesuai dengan penjabaran di atas bahwa subjek diberikan intervensi berupa terapi bermain berbasis CBPT tersebut mempunyai hasil positif.

\section{Kesimpulan.}

Berdasarkan hasil penelitian yang telah dilakukan disimpulkan bahwa, terapi bermain berbasis CBPT (Cognitive Behavioral Play Therapy) efektif dapat meningkatkan perilaku konsentrasi anak ADHD.

\section{Saran}

Penelitian ini peneliti hanya melakukan penelitian selama 10 sesi dengan jangka waktu yang singkat, maka perilaku konsentrasi subjek belum dikatakan meningkat sepenuhnya atau stabil. Bagi peneliti selanjutnya, sebaiknya intervensi dilakukan dalam jangka waktu yang lebih lama agar mendapatkan hasil yang terlihat perubahannya. Berdasarkan hasil dan temuan penelitian bahwa terdapat faktor lain yang mempengaruhi peningkatan konsentrasi subjek seperti terapi yang pernah diberikan kepada subjek sebelumnya, pola asuh dilingkungan keluarga dan juga pola asuh dilingkungan sekolah, sebaiknya lebih mengontrol faktor-faktor tersebut untuk menambahkan validitas data.

\section{Referensi}

Adriana, Dian. (2011). Tumbuh Kembang \& Terapi Bermain pada Anak. Jakarta:

Salemba Medika.

Alfiyanti, Dera, dkk. (2007). Pengaruh Terapi Bermain Terhadap Tingkat 
Kecemasan Anak Usia Prasekolah Selama Tindakan Keperawatan di Ruang Lukman Rumah Sakit Roemani Semarang. Jurnal Keperawatan Vol. 1 No. 1 - Oktober $2007: 35$ - 44.

Alwisol. (2009). Psikologi Kepribadian. Malang: UMM Press. Anjani, Ayu Tri, dkk. Studi Kasus Tentang Konsentrasi Belajar pada Anak ADHD (Attention Deficit Hyperactivity Disorder) Di SDIT At-Taqwa Surabaya dan SDN V Babatan Surabaya .Jurnal BK UNESA, Volume 1 Edisi 2.

Azwar, Saifuddin. (2012). Reliaibilitas dan Validitas.Yogyakarta: Pustaka Pelajar.

Baihaqi, Sugiarmin. (2006). Memahami dan Membantu Anak ADHD. Bandung: PT. Riefka Aditama.

Braverman, Lisa dan Kevin J. O'Cornoor (2009). Play Therapy Theory Andpractice Comparing Theories and Thecniques. Hoboken: New Jersey: Canada.

Choi, Jin-Ah (2012). Literature Review of Play Therapy Intervention for Children with ADHD. Journal of the Korean Home Economics Association. Vol 50(5):125-138.

Corey, Gerald.(2005). Teori dan Praktek Konseling \& Psikoterapi. Bandung: P.T Riefka Aditama.

Davidson, Gerald, Jhon M. Neale, dan M. Kring Ann. (2012). Psikologi Abnormal. Jakarta: Rajawali Press.

Flanagen, Robb. (2005). ADHD Kids Menjadi Pendamping Bijak Bagi Anak Penderita ADHD Bijak. Jakarta: PT. Prestasi Pustakarya.

F. Naderi, A. Heidarie, L. Bouron and P. Asgari, (2010). "The Efficacy of Play Therapy on ADHD, Anxiety and Social Maturity in 8 to 12 Years Aged Clientele Children of Ahwaz Metropolitan Counseling Clinics," Journal of Applied Sciences, Vol. 10, No. 3.

Hall, T.M., Kaduson, H.G., and Schaefer C.E. (2002). Fifteen Effective Play Therapy Techniques. Professional Psychology: Research and Practice, 515-522.

Hatiningsih, Nuligar (2013). Play Therapy untuk Meningkatkan Konsentrasi pada Anak Attention Deficit Hyperactive Disorder (ADHD) Jurnal Psikologi Terapan, ISSN: 2301-8267 Vol. 01, No.02, Agustus 2013.

Iffa Dwi Hikmawati, Erny Hidayati. (2014). Efektivitas Terapi Menulis untuk Menurunkan Hiperaktivitas dan Impulsivitas Pada Anak dengan Attention Deficit Hyperactivity Disorder (ADHD). Juli 2014. Empathy. Jurnal Fakultas Psikologi, Universitas Ahmad Dahlan.Vol. 2, No 1ISSN : 2303-114X.

Isnawati, Erma. (2008). Mendidik Anak dengan Bermain.Yogyakarta: Arti Bumi Intaran.

Latipun.(2015). Psikologi Eksperimen.Malang: UMM Press.

L, Barzegary. dan Zamini, S . (2011). The Effect of Play Therapy on Children with ADHD. journal Social and Behavioral Sciences. Vol 30: 2216 - 2218.

Linda E. Homeyer and Mary O. Morrison. (2008) Play Therapy Practice, Issues, and Trends. by the Board of Trustees of the University of Illinois.

Olga Pykhtina, Balaam, Madeline etc. (2012) Designing for Attention Deficit Hyperactivity Disorder in Play
Therapy: the case of Magic Land. ACM 978-1-45031210-3.

Pentecost, David. (2004). Menjadi Orang Tua Anak ADD/ADHD Tidak Sanggup? Tidak Mau? Jakarta: Dian Rakyat.

Pternotte, Arga, dan Jan Buitelar, (2010). ADHD Attention Deficit Hiperativity Disorder (Gangguan Pemusatan Perhatian dan Hiperaktivitas) Gejala, Diognosis, Terapi, serta Penaganannya di Rumah dan di Sekolah. Jakarta: Prenada Media Group.

Putri, Ratih Pratiwi, dan Afin Murtiningsih, (2013). Kiat Sukses Mengasuh Anak Berkebutuhan Khusus, Yogyakarta: Ar-Ruzz Media.

Rusmawati, Diana dan Dewi, Endah Kumala. (2011). Pengaruh Musik dan Gerak Terhadap Penurunan Perilaku Siswa Sekolah Dasar dengan Gangguan ADHD. Jurnal Psikologi UNDIP. Vol. 9, No. 1.

Santoso, Hargio. (2012). Cara Memahami dan Mendidik Anak Berkebutuhan Khusus, Yogyakarta:Gosyen Publishing.

Schaefer, Charles. E . (2011). Foundations of Play Therapy Second Edition. Canada: John Wiley dan Sons, Inc., Hoboken, New Jersey.

Sholichatun, Yulia. (2014). Handout Kuliah Modifikasi Perilaku (Edisi Revisi). Fakultas Psikologi Universitas Islam Negeri Malang.

Stenberg, Robert J. (2008). Psikologi Kognitif. Yogyakarta: Pustaka Belajar.

Sunanto, Takeuchi, Nakata, (2005). Pengantar Penelitian dengan Subyek Tunggal.CRICED University of Tsukuba.

Tim Dosen Pengampu PD 2. (2009) hand out mata kuliah observasi Fakultas Psikologi UIN Malang.

Veskarisyanti, Galih A. (2008). 12 Terapi Autis Paling Efektif dan Hemat untuk Autisme, Hiperaktif, dan Retardasi Mental, Yogyakarta: Pustaka Anggrek.

Zellawati, Alice. (2011). Penerapan "Caregiver Skill Program" untuk Mereduksi Inatensi pada Anak ADHD. Mei 2011. Majalah Ilmiah Informatika Fakultas Psikologi Universitas AKI.Vol. 2 No. 2. 